\title{
SCREENING OF WOODY AND SHRUB LEGUMES FOR AGRO-FORESTRY SYSTEMS BASED ON BIOMASS PRODUCTION, N YIELD AND BIOLOGICAL $\mathrm{N}_{2}$ FIXING CAPACITY
}

\author{
W D L Gunaratne, A P Heenkenda, K V S Premakumara and W M S R Bandara \\ Department of Export Agriculture, Research Station, \\ Matale.
}

A field study was carried out to identify the suitable tree species for agroforestry systems based on their biomass production. $\mathrm{N}$ yield and $\mathrm{N}_{2}$-fixing capacity at the Export Agriculture Reseatch Station. Matale for a period of 9 months. ${ }^{15} \mathrm{~N}$ isotope dilution method was used for the assessment of the proportion of $\mathrm{N}_{2}$ derived through fixation (Pfix). Gliricidia syium (gliricidia). Calliamdra calothyrsus (calliandra). Le'ucacna leweocephala (leucacna). Erythrima subumbrance (Erythrina), Albizia falcataria (Albicia) and Acacia mangium (acacia) were used as $\mathrm{N}_{2}$-lixing species and Semne siamed (siamea). Senma spercabilis (Spectabilis), both are non-nodulating legumes, and Michaclia champaca (michalia) were used as non $\mathrm{N}_{2}$-fixing reference species.

Total dry matter yield of non $\mathrm{N}_{2}$-lixing reference crop spectabilis was significantly (p0.05) higher than all the species. Among the fixing species, Calliandra produced the highest biomass though the value is not significantly $(p \geq 0.05)$ different from gliricidia. leucaenat and siamea. Acacia and michaclia recorded the lowest yields.

Highest leatl. twigs and root $\mathrm{N} \%$ wals found in erythrina and the highest trunk $\mathrm{N} \%$ was associated with gliricidia. Leaf $\mathrm{N} \%$ of spectabilis was less than that of gliricidia and erythrina but total $\mathrm{N}$ yield of spectabilis was the highest due to high biomass production. Among the six lixing species highest $N$ yield was found with calliandra and the value is over two fold higher than that for gliricidia. Acacia and michaclia recorded the lowest $n$ yiclds.

Highest Pfix values for whole plant was found with albizia followed by gliricidia. calliandra, crythrina, Icuceana and acacia. The trend is common for the values based on all the three reference crops. Tolal $\mathrm{N}_{2}$-fixing capacity of calliandra recorded the highest value followed by leucaena. gliricidia. albizia, erythrina, and acacia. $\mathrm{N}_{2}$-fixing values calculated based on siamea and spectabilis revealed $\mathrm{N}$-fixing species calliandra, Ieucaena and gliricidia have the capacity to fix $19.51-23.11,15.77-19.79$ and $13.10-14.42 \mathrm{~g} \mathrm{~N}$ pliant ${ }^{-1}$. The values equivalent to 195-231. 158-198 and 131-144kg of $\mathrm{N} \mathrm{ha}^{-1}$ ).

S. spectabilis, $C$. calothyrsus, L. leucorephala and $G$. sepium produced higher biomass and higher $\mathrm{N}$ yields over the others. Total $\mathrm{N}$ fixing capacity of $C$. calothyrsus, $L$. leucocephala and $G$. sepium were superior to the other species. However, where maintenance of soil $\mathrm{N}$ status is considered further studies are recommended to evaluate the litter quality and $\mathrm{N}$ transferring ability before a firm recommendation is made.

Procededings of the Fomrth Ammal Forestry and Enviromment Sympesimm 1998 af the Department of Fonestry and Emirommental Science. University of Siri Iayenardenepura. Sri Lamka 